\title{
Manfaatkan Sampah Rumah Tangga Menjadi Kompos di Kecamatan Minas Kabupten Siak
}

\author{
Latifa Siswati ${ }^{1}$, Ambar Tri Ratna Ningsih², Hamzah Eteruddin ${ }^{3}$ \\ Universitas Lancang Kuning \\ latifasiswati@unilak.ac.id, ambar@unilak.ac.id, hamzah@unilak.ac.id
}

\begin{abstract}
Abstrak
Sampah rumah tangga dapat dimanfaatkan menjadi kompos yang digunakan sebagai pupuk bagi tanaman, umumnya masyarakat memiliki pekarangan yang dapat ditanamani bunga, sayur dan buah. Pengolahan sampah rumah tangga selain untuk dijadikan kompos sekaligus untuk membersihkan lingkungan rumah juga, memberikan kontribusi dalam masalah pengelolaan sampah di daerah, serta mengurangi pengeluaran rumah tangga untuk membeli pupuk bagi tanaman, meminimalkan pemakaian pupuk kimia. Kecamatan Minas berjarak $8 \mathrm{~km}$ dari Universitas Lancang Kuning, belum ada masyarakat memanfaatkan sampah menjadi kompos. Pengelola bank sampah belum memiliki keterampilan dan pengetahuan ini sehingga sampah rumah tangga belum diolah menjadi kompos, memberi penyadaran kepada masyarakat untuk peduli kepada lingkungan apabila tidak ada kesadaran masyarakat untuk mengolah sampah menyebabkan sampah semakin banyak. Metode kegiatan yang diberikan kepada masyarakat adalah, penyadaran, penyuluhan, demonstrasi, dan evaluasi. Untuk mempercepat proses pengomposan diberi bioaktifator. Setelah dilakukan pelatihan terjadi peningkatan pengetahuan peserta 13,33\% sampai 93,33\%. Lingkungan jadi bersih.
\end{abstract}

Kata Kunci : sampah rumah tangga, kompos, lingkungan

\begin{abstract}
Every day organic waste is generated from household activities, including from building houses and activities in the kitchen. One of the household waste processing technologies is to use waste into compost. Processing waste into compost provides beneficial values for the community, namely to clean the home environment, contribute to waste management problems in the regions, reduce household expenses for buying fertilizer for plants and minimize the use of chemical fertilizers. The transfer of knowledge and skills to process household waste into compost was carried out in Minas District, Siak Regency, Riau Province. Partners are managers of the Periodic Waste Bank and the community who have not used waste into compost and do not have the skills to make compost. The method used is in the form of socialization and awareness to the public to care for the environment and demonstrations to process household waste into compost and evaluation. After the training activities were carried out, there was an increase in the participants' knowledge by $13.33 \%$ to $93.33 \%$. The community already has the skills to make compost, as evidenced by the product in the form of compost and its application to plants.
\end{abstract}

Keywords: household waste, compost, environment 


\section{PENDAHULUAN}

Setiap rumah tangga selalu menghasilkan sampah, jika tidak diolah akan menimbulkan masalah pada masyarakat yang menimbulkan bau tidak sedap dan dapat merusak lingkungan. Dalam upaya mengurangi pencemaran udara yang diakibatkan limbah rumah tangga, beberapa daerah berusaha mulai mendirikan program bank sampah. Dengan program ini pengurus berusaha meminimalisir sampah yang ada dengan metode Reuse, reduce, dan recycle (3R) (Nugraha, Sutjahjo, and Amin 2018; Subekti 2010).

Pengelolaan bank sampah harus dilakukan secara berkesinambungan. Pengelolaan sampah dimulai dari pemilahan yang dilakukan di rumah sebelum dibuang. Sampah yang telah dipilah akan memudahkan proses pengelolaan sampah yang selanjutnya. Partisipasi masyarakat juga diperlukan dalam mengelola sampah baik secara langsung maupun tidak langsung menjadi suatu bentuk benda lain yang memiliki manfaat. Partisipasi merupakan modal yang penting bagi program pengelolaan sampah, untuk dapat berhasil mengatasi permasalahan mengenai sampah rumah tangga yang banyak terdapat di lingkungan masyarakat, terutama di perkotaan. Partisipasi aktif dari masyarakat dalam mengelola sampahnya dan dapat dimulai dari rumah tangga dengan cara pemilahan sampah organik, sampah anorganik mapun sampah B3 sehingga nantinya yang terangkut ke TPA hanya sisanya saja. Keberhasilan pengurus bank sampah dalam meningkatkan pengetahuan dan pengelolaan sampah, akan sangat membantu mewujudkan kampung atau desa yang lebih ramah lingkungan. Apalagi jika mendapat dukungan dari pemerintah kota dan instansi terkait, khususnya Dinas Lingkungan Hidup (DLH). Dukungan dapat berupa sosialisasi informasi, pendampingan, pemantauan dan penyuluhan yang dilakukan secara berkelanjutan agar Bank Sampah dapat mandiri.

Sampah organik rumah tangga dapat diolah menjadi pupuk kompos yang dapat digunakan sebagai pupuk untuk tanaman (Siswati, Ningsih, and Jeniwardi 2019; Subekti 2010). Hal ini dapat dimanfaatkan masyarakat, yang umumnya memiliki pekarangan yang dapat ditanamani bunga, sayur dan buah (Sahwan, Wahyono, and Suryanto 2016; Setyaningsih, Setyo Astuti, and Astuti 2017). Pengolahan sampah rumah tangga selain untuk dijadikan kompos sekaligus untuk membersihkan lingkungan rumah juga, memberikan kontribusi dalam masalah pengelolaan sampah di daerah, serta menguranggi pengeluaran rumah tangga untuk membeli pupuk bagi tanaman, meminimalkan pemakaian pupuk kimia. Sementara sampah anorganik dapat dirubah menjadi bentuk lain sehingga bernilai ekonomis serta dapat dijadikan briket sampah (Marliani 2014; Putra and Yuriandala 2010).

Bank Sampah Benawa Raya Mandiri (BRM), melaksanakan program ini dan terjadi peningkatan kesadaran ibu-ibu yang berada di kota Banjarbaru dalam hal pembuangan dan pengelolaan sampah mencapai $80 \%$ (Rachmawati, Susilawati, and Prihatiningtyas 2019). Sementara berdirinya Bank Sampah Samawa (BSS) di desa Penyaring NTB, lebih dikenal masyarakat setelah adanya berita pada koran Gaung. Bank sampah ini memiliki $70 \%$ anggota kelompok mitra aktif dalam melaksanakan kegiatan pengolahan sampah skala rumah tangga (Mardhia and Wartiningsih 2018). Hal ini dicapai bermodal anggota kelompok yang memahami pengelolaan sampah skala rumah tangga, sehingga dapat meningkatkan jumlah nasabah yang ada.

Nasabah Bank Sampah Rawajati (BSR) 96,77\% menyetujui sampah harus dikelola setiap hari, karena sampah yang menumpuk akan berdampak buruk pada lingkungan (Nugraha et al. 2018). Persepsi nasabah Bank Sampah Rawajati terhadap pengelolaan sampah rumah tangga secara keseluruhan adalah positif dan partisipasi masyarakat dalam pengelolaan sampah rumah tangga secara keseluruhan sudah tinggi. Semakin baik persepsi masyarakat terhadap pengelolaan sampah rumah tangga, maka akan semakin tinggi tingkat partisipasi.

Hasil penelitian menunjukkan bahwa potensi reduksi sampah oleh perumahan permanen adalah sebesar 53\% sampah mudah membusuk yang berpotensi untuk pengomposan dan 17\% sampah anorganik untuk daur ulang yang jika dijual kepada masyarakat bisa memiliki potensi sampai Rp. 672,125 perhari (Windraswara and Prihastuti 2017). Sementara pada perumahan kos permanen potensi reduksi sampah adalah sebesar $16 \%$ sampah organik untuk pengomposan dan 47\% sampah anorganik untuk daur ulang (Windraswara and Prihastuti 2017).

Lingkungan Hidup \& Kebencanaan Covid-19

499 
Penduduk Kecamatan Minas Kabupaten Siak berjumlah 28.240 orang (Kecamatan Minas) dalam waktu satu bulan menghasilkan sampah sebanyak $423.600 \mathrm{~kg}$ yang lebih dari 60 persen adalah sampah organik (BPS Siak 2019). Jika sampah diolah menjadi pupuk kompos dapat mengurangi dampak lingkungan dan dapat mengurangi pemakaian pupuk anorganik. Selama ini di Kecamatan Minas belum ada yang mengolah sampah organik menjadi pupuk kompos. Sampah dari rumah tangga dan sampah lainnya biasa di bakar yang menimbulkan asap yang menganggu pernafasan. Di Minas belum ada bank sampah maka Tim dari Universitas Lancang Kuning membantu mendirikan bank sampah.

Program ini perlu sosialisasi kepada masyarakat tentang pengeloaan sampah rumah tangga dapat dimanfaatkan menjadi pupuk kompos, perlu kesadaran masyarakat untuk memilah sampah dari rumah berupa sampah organik dan anorganik yang selama ini belum pernah mereka lakukan daun gugur, sampah dari sisa pertanian, sampah dari sayuran dapur, dan jenis sampah organik lainnya. Bisa diolah sendiri oleh masyarakat menjadi pupuk kompos, yang tentunya akan memberikan manfaat yang lebih kepada masyarakat.

Kegiatan ini merupakan salah satu dari Tri darma Perguruan tinggi yaitu pengabdian kepada masyarakat dimana tim dapat mengaplikasian ilmu langsung kepada masyarakat, merupakan percontohan bagi masyarakat di kecamatan Minas.

Tujuan kegiatan ini adalah untuk meningkatkan pemahaman sampah rumah tangga dapat bermanfaat menjadi pupuk kompos serta meningkatkan pengetahuan mitra dengan penyadaran, dan demonstrasi, dan mengajak masyarakat mengelola sampah organik yang ada di lingkungannya untuk dijadikan kompos.

\section{METODE}

Kegiatan dilakukan di Kantor Camat Minas pada tanggal 27 Juni 2020 dengan jumlah perserta 15 orang, hal ini peserta dibatasi karena masih suasana covid 19 dimana tidak boleh berkumpul banyak orang. Kegiatan yang dilakukan oleh tim adalah : satuSosialisasi dan koordinasi dengan masyarakat melalui bapak Camat Minas

Dua Memilah sampah rumah tangga organik dan anorganik
Tiga .Pelatihan dan demonstrasi membuat pupuk kompos dari sampah rumah tangga.

Empat Mengedukasi masyarakat untuk tidak membakar sampah

Lima Memberikan pelatihan pemasaran.

Enam Evaluasi kegiatan dengan memberikan

kuisioner setelah melakukan pelatihan.

\section{HASIL DAN PEMBAHASAN}

\section{Sosialisasi dan Penyadaran}

Peserta sosialisasi adalah mitra yang merupakan wakil disetiap kelompok masyarakat dari Kampung dan kelurahan yang ada di Kecamatan Minas, peserta sebanyak 15 orang. Koordinasi dengan Bapak Camat dan jajarannya serta pemuka masyarakat sangat membantu kegiatan ini untuk menyampaikan kegiatan ini kepada peserta. Bapak Camat Minas sangat antusias dan menyambut baik adanya kegiatan ini karena memberikan solusi penanganan sampah yang ada di wilayahnya juga membentu program pemerintah dalam penangulangan sampah. Kegiatan ini dilakukan di kantor Camat Minas, dan dihadiri juga oleh Tim dari PT. Chevron Pacific Indonesia selaku pemberi dana.

Tim pengabdian juga memberikan pemahaman kepada peserta betapa pentingnya kita mengolah sampah rumah tangga menjadi pupuk kompos diharapkan peserta yang mewakili kelompoknya dapat memotivasi dan menularkan ilmu yang di peroleh melalui sosialisasi ini. Pada saat sebelum mendapat sosialisasi penetahuan megolah sampah rumah tangga menjadikan kompos sangat minim, sebagaimana terlihat pada Gambar 1 dan 2 .

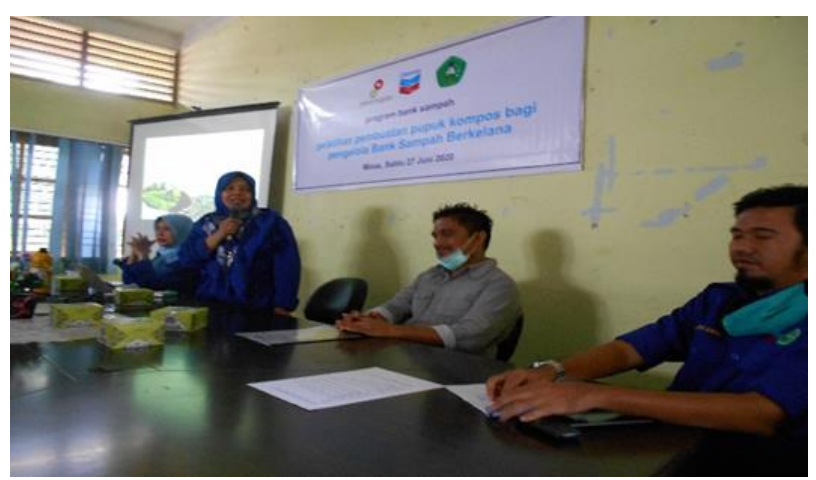

Gambar 1. Sosialisasi menanfaatkan sampah menjadi pupuk kompos

Lingkungan Hidup \& Kebencanaan Covid-19 
Dengan meanfaatkan sampah menjadi pupuk kompos dapat mengurangi kerusakan lingkungan dimulai dari hal hal yang kecil yaitu dengan memperlakukan sampah dengan metode Reuse, reduce, dan recycle (3R). Penerapan $3 \mathrm{R}$ menjadi salah satu solusi dalam menjaga lingkungan yang mudah dan murah untuk dilakukan disamping mengolah sampah menjadi kompos atau memanfaatkan sampah menjadi pupuk kompos.

\section{Pelatihan}

Pelatihan memanfaatkan sampah rumah tangga menjadi pupuk kompos dikuti sangat antusias oleh perserta karena selama ini sampah rumah tangga di Kecamatan Minas belum dimanfaatkan oleh masyarakat. demonstrasi pemanfaatan sampah rumah tangga untuk memotong sampah masih belum ada alat pencacah jadi masih dengan mengunakan parang sehingga hasil potongan kurang halus. Setiap sesi kegiatan pengolahan sampah rumah tangga menjadi pupuk kompos diikuti dan diperhatikan oleh peserta dengan sangat baik dan antusias, sebagaimana terlihat pada Gambar 2 dan 3.

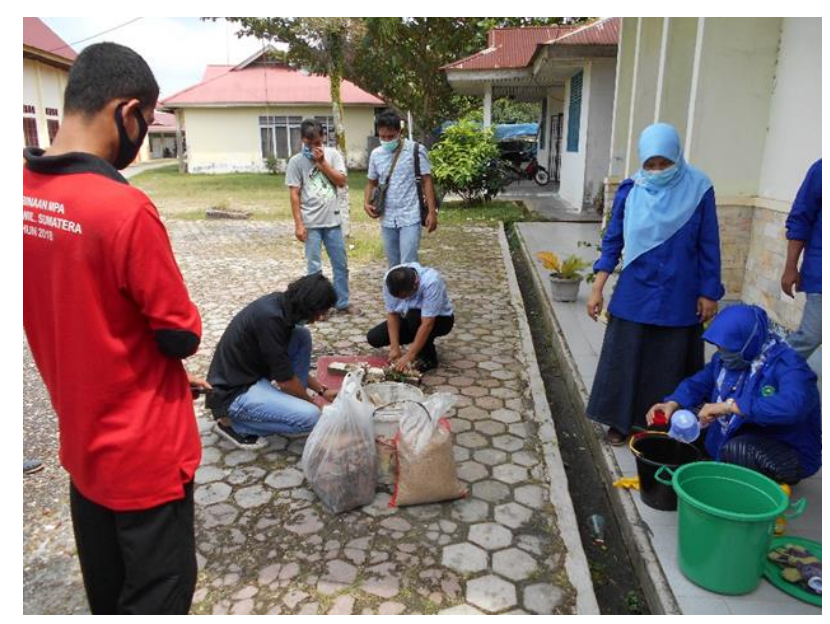

Gambar 2. Pelatihan pembuatan pupuk kompos dari sampah organik rumah tangga

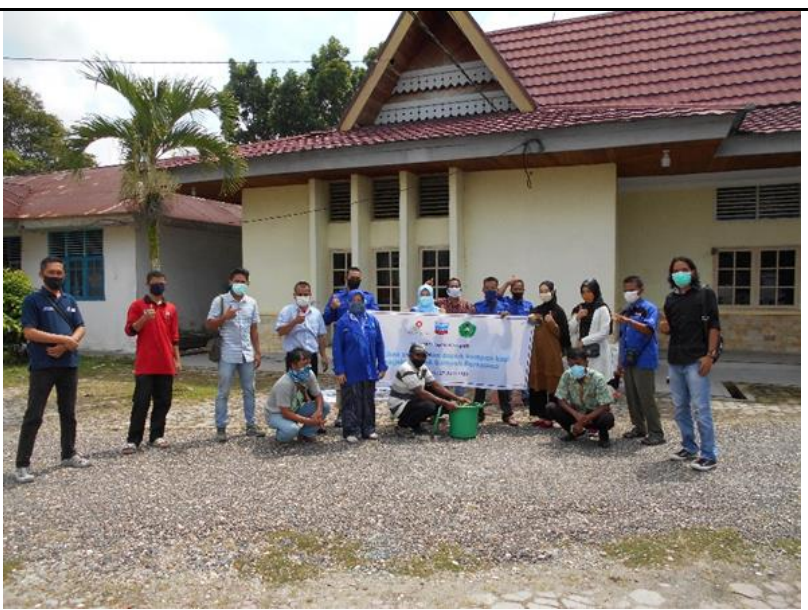

Gambar 3. Selesai pelatihan pengolahan sampah organik menjadi pupuk kompos

Pembuatan pupuk kompos dengan cara mencacah sampah orgnik rumah tangga lebih kecil dan ditambahkan sekam padi, pupuk kompos dan di berikan EM4 yang sudah dicampur dengan gula, diaduk rata kemudian dimasukan ke dalam wadah pengomposan selama empat minggu setiap minggu diaduk supaya rata. Setelah jadi kompos berwarna kecoklatan sudah dapat digunakan sebagai pupuk kompos bagi tanaman, sebagaimana terlihat pada Gambar 4.

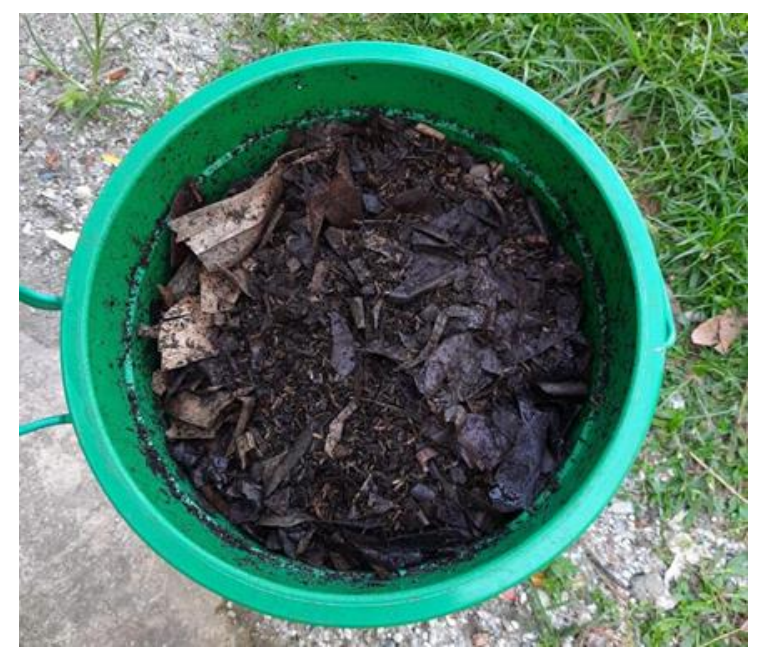

Gambar 4. Pupuk kompos hasil pengolahan sampah organik rumah tangga

\section{Evaluasi Kegiatan}

Untuk mengetahui tingkat keberhasilan kegiatan maka dilakukan pengukuran pengetahuan dan pemahaman peserta sebelum dan sesudah kegiatan 
pelatihan. Sebelum kegiatan pelatihan mitra diberikan pre test ntuk mengukur tingkat pemahaman mitra terkait materi yang akan disampaikan. Pertanyaan terkait pengertian sampah, jenis-jenis sampah, pengelolaan sampah, manfaat kompos, alat dan bahan dalam pembuatan kompos dan proses pembuatannyaa. Setelah dilakukan pelatihan diberikan test dengan kuisoner yang sama dengan test sebelumnya. Hasil kuisoner menunjukan bahwa mitra sudah mengetahui tentang manfaat kompos dan proses pembuaatannya.

Persentase peningkatan pengetahuan dan pemahaman mitra dapat dilihat pada tabel 1 .

Tabel 1. Peningkatan Pengetahuan Setelah Kegiatan

\begin{tabular}{lc}
\hline \multicolumn{1}{c}{ Materi pelatihan } & $\begin{array}{c}\text { Peningkatan } \\
\text { pengetahuan } \\
(\%)\end{array}$ \\
\hline Mengikuti pelatihan & 60 \\
Sampah organik rumah tangga & 13,33 \\
Manfaat pupuk kompos & 40 \\
Bahan kompos & 46,67 \\
Bioaktifator EM 4 & 60 \\
Ciri-ciri kompos matang & 60 \\
Alat yang digunakan & 46,67 \\
Menyukai pupuk organik sebagai pupuk & 40 \\
tanaman & \\
Cara membuat kompos & 53,33 \\
Pernah memanfaatkan pupuk kompos & 53,33 \\
Berminat menjadi pengusaha pupuk & 20 \\
kompos & \\
Pernah mengolah sampah organik rumah & 93,33 \\
tangga menjadi kompos & \\
\hline
\end{tabular}

Berdasarkan tabel satu diketahui terjadi peningkatan pengetahuan peserta dalam membuat kompos sebesar 53,33\%. Sebagian besar peserta sering mendengar istilah kompos dan mengetahui manfaatnya sebagai pupuk organik tetapi belum bisa membuatnya dengan memanfaatkan sampah rumah tangga. Peningkatan pengetahuan peserta tertinggi sebesar $60 \%$ terhadap ciri-ciri kompos yang sudah matang daan siap untuk digunakan sebagai pupuk. Peningkatan pengetahuan terendah sebesar 13,33\% pada sampah organik rumah tangga, halini disebabkan sebelum pelatihan peserta sudah mengetahui sampah organik rumah tangga. manfaat kompos setelah dilaksanakan pelatihan pengetahuan meningkat $40 \%$. Bahan untuk membuat kompos terjadi peningkatan pemahaman sebesar $46,67 \%$. untuk pemakaian bioaktifator terjadi peningkatan $60 \%$ dimana sebelum pelatihan sebagian peserta sudah mengetahui fungsi biokatifator, ciri-ciri kompos matang terjadi peningkatan $60 \%$, Sebagian besar peserta $93,33 \%$ berkeinginan untuk mempraktekan pelatihan ini dengan mengolah sampah rumah tangga menjadi kompos karena selama ini belum pernah membuat kompos dari sampah organik rumah tangga .Berdasarkan hasil penelitian Windraswara, R., \& Prihastuti, D. A. B. (2017) menunjukkan bahwa sebesar 53\% sampah organik dari perkotaan mudah membusuk yang berpotensi untuk pengomposan

Jika dibandingkan hasil pelatihan pengolahan sampah menjadi kompos di beberapa daerah menunjukaan setelah pelatihan keinginan peserta untuk memaanfaatkan sampah yang ada di lingkungannya sangat besar. Rachmawati, N., Susilawati, S., \& Prihatiningtyas, E. (2019), peningkatan kesadaran ibu ibu pengurus Bank Sampah Benawa Raya kota Banjarbaru dalam hal pembuangan dan pengelolaan sampah mencapai $80 \%$ setelah dilaksanakannya pelatihan. Dengan adanya pelatihan pengolahan sampah rumah tangga menjadi kompos, diharapkan Bank Sampah Berkelana dapat mengolah sampah organik menjadi kompos dan memasarkannya sebagai produk unggulan. Mardhia, D., \& Wartiningsih, A. (2018) menyatakan berdasarkan dari kegiatan pelatihan pengolahan sampah di NTB diketahui satu.70\% anggota kelompok mitra aktif dalam melaksanakan kegiatan pengolahan sampah skala rumah tangga ,dua. Anggota kelompok sebagian besar telah memahami pengolahan sampah skala rumah tangga ,tiga .jumlah nasabah Bank Sampah bertambah menjadi 30 nasabah. Pengelolaan sampah harus dilakukan secara berkesinambungan, Partisipasi masyarakat dalam pengelolaan sampah di Bank Sampah merupakan keterlibatan masyarakat secara langsung maupun tidak langsung dalam upaya mengelola sampah menjadi suatu benda lain yang memilki manfaat. Partisipasi merupakan modal yang penting bagi program pengelolaan sampah untuk dapat berhasil mengatasi permasalahan mengenai sampah rumah tangga yang banyak terdapat di lingkungan masyarakat, terutama di Lingkungan Hidup \& Kebencanaan Covid-19 $\quad 502$ 
perkotaan (Nugraha, A., Sutjahjo, S. H., \& Amin, A. A. (2018).

Pada pelatihan ini, tim melakukan pendampingan kepada mitra dalam mengolah sampah rumah tangga menjadi kompos. Bak Sampah Berkelana telah mampu memproduksi kompos dan memanfaatkan pupuk kompos untuk meningkatkan kesuburan tanah pada budidaya sayur. Hasil dan aplikasi pupuk kompos pada tanaman dapat dilihat pada gambar 5 .

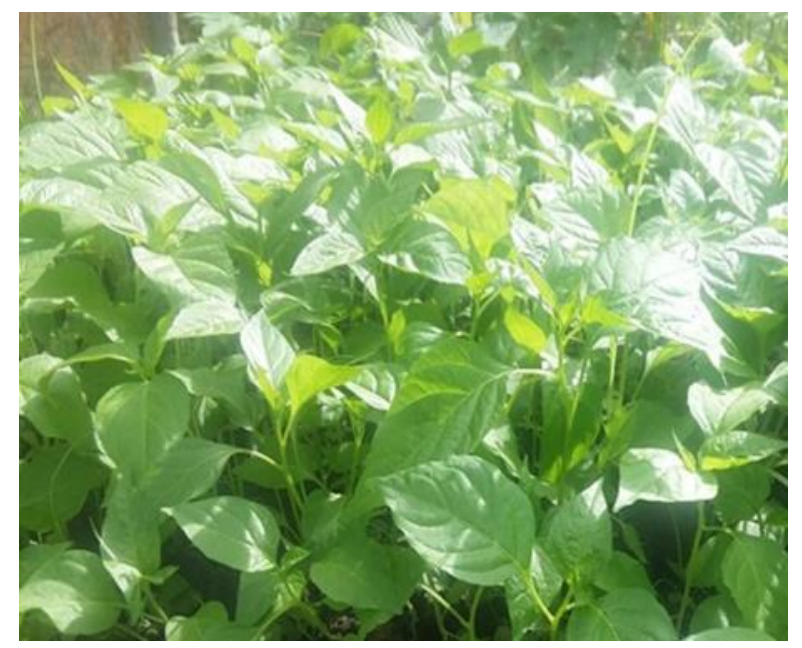

Gambar 5. Tanaman yang telah di beri Pupuk Kompos

\section{KESIMPULAN}

Hasil kegiatan disimpulkan dapat meningkatan pengetahuan, pemahaman, dan keterampilan peserta berkisar antara 13,33\%93,67\%. Dan kecepatan pengomposan sangat tergantung dari ukuran bahan organik yang dijadikan bahan untuk kompos, semakin kecil ukuran potongan bahan organik maka proses pengomposan akan semakin cepat. Bio aktifator yang digunakan berperan dalam mempercepat proses pengomposan, selain itu kehomogenan bahan juga menjadi pertimbangan dalam pengomposan.

\section{SARAN}

Saran yang dianjurkan adalah melanjutkan pengolahan sampah rumah tangga tidak hanya sampah organik tetapi sampah plastik juga perlu mendapat perhatian, karena sampah plastik yang memerlukan waktu lama bisa terurai..

\section{UCAPAN TERIMAKASIH}

Ucapan terimakasih ditujukan kepada PT. Chevron Pacific Indonesia yang telah mendanai kegiatan ini dan Camat Kecamatan Minas beserta jajarannya yang telah memberikan kesempatan untuk melakukan kegiatan pengabdian di wilayah administratifnya, dan terimakasih diucapkan kepada pimpinan Unilak yang telah memberikan bantuan finansial dalam melaksanakan kegiatan ini.

\section{REFERENSI}

BPS Siak. 2019. Kecamatan Minas Dalam Angka. Siak: M\&N Grafika.

Mardhia, Dwi and Alia Wartiningsih. 2018. "Pelatihan Pengolahan Sampah Skala Rumah Tangga Di Desa Penyaring." Jurnal Pendidikan Dan Pengabdian Masyarakat 1(1):88-96.

Marliani, Novi. 2014. "Pemanfaatan Limbah Rumah Tangga ( Sampah Anorganik ) Sebagai Bentuk Implementasi." Jurnal Formatif 4(2):124-32.

Nugraha, Aditya, Surjono H. Sutjahjo, and Akhmad Arif Amin. 2018. "Analisis Persepsi Dan Partisipasi Masyarakat Terhadap Pengelolaan Sampah Rumah Tangga Di Jakarta Selatan.” Jurnal Pengelolaan Sumberdaya Alam Dan Lingkungan (Journal of Natural Resources and Environmental Management) 8(1):7-14.

Putra, Hijrah Purnama and Yebi Yuriandala. 2010. "Studi Pemanfaatan Sampah Plastik Menjadi Produk Dan Jasa Kreatif." Jurnal Sains \&Teknologi Lingkungan 2(1):21-31.

Rachmawati, Normela, Susilawati Susilawati, and Eva Prihatiningtyas. 2019. "Pengolahan Sampah Organik Menjadi Kompos Untuk Mendukung Kampung Pro Iklim." Jurnal Pengabdian Al-Ikhlas 4(2).

Sahwan, Firman, Sri Wahyono, and Feddy Suryanto. 2016. "Kualitas Kompos Sampah Rumah Tangga Yang Dibuat Dengan Menggunakan "Komposter" Aerobik." Jurnal Teknologi Lingkungan 12(3):233-40.

Setyaningsih, Endang, Dwi Setyo Astuti, and Rina Astuti. 2017. "Kompos Daun Solusi Kreatif Pengendali Limbah.” Bioeksperimen: Jurnal 
Penelitian Biologi 3(2):45-51.

Siswati, Latifa, Ambar Tri Ratna Ningsih, and Jeniwardi. 2019. "Pengolahan Sampah Rumah Tangga Menjadi Kompos Di Kelurahan Labuh Baru Timur Pekanbaru." Pp. 660-65 in PKM CSR. Vol. 2.

Subekti, Sri. 2010. "Pengelolaan Sampah Rumah Tangga 3R Berbasis Masyarakat." Pp. 1.241.30 in Seminar Nasional Sains dan Teknologi. Vol.
1. Semarang: Fakultas Teknik Universitas Wahid Hasyim.

Windraswara, Rudatin and Dyah Ayu Bunga Prihastuti. 2017. "Analisis Potensi Reduksi Sampah Rumah Tangga Untuk Peningkatan Kualitas Kesehatan Lingkungan." Unnes Journal of Public Health 6(2):123. 